Available Online at www.jbpr.in CODEN: - JBPRAU (Source: - American Chemical Society) PubMed (National Library of Medicine): ID: (101671502) Index Copernicus Value 2017: 92.04

Research Article Volume 8, Issue 1: January-February: 2019, 20-29

\title{
EVALUATION OF ANTI-DIABETIC ACTIVITY OF TERMINALIA ARJUNA ROOT EXTRACT IN ALLOXAN INDUCED DIABETIC RATS
}

\author{
Shikha Singh, Neeru Shukla, Mithun Bhowmick, Jagdish Rathi \\ NRI Institute of Pharmaceutical Sciences, Bhopal
}

\section{Article Info: Received 14 December 2018; Accepted 05 January. 2019}

Cite this article as: Singh, S., Shukla, N., Bhowmick, M., \& Rathi, J. (2019). EVALUATION OF ANTI-DIABETIC ACTIVITY OF TERMINALIA ARJUNA ROOT EXTRACT IN ALLOXAN INDUCED DIABETIC RATS. Journal of Biomedical and Pharmaceutical Research, 8(1).

DOI: https://doi.org/10.32553/jbpr.v8i1.566

Address for Correspondence: Shikha Singh, NRI Institute of Pharmaceutical Sciences, Bhopal

Conflict of interest statement: No conflict of interest

\section{ABSTRACT:}

The present study was carried out to evaluate the effect of root extract of Terminalia arjuna on blood glucose level of normal and diabetic rats was evaluated in this study. Physicochemical investigations were performed on the acetone extract of Terminalia arjuna (roots). 15-day treatment of extracts associated with reduced the elevated levels of TC, TG as compared to negative control in diabetic animals. The data obtained from this study showed that the treatment of extracts and glibenclamide protects the diabetic rats from massive body weight loss, when given orally, daily for 15 days. Evaluation of anti-diabetic activity of terminalia arjuna showed that the root extract of Terminalia arjuna have potent antidiabetic effects in alloxan-induced diabetic rats.

Keywords: Terminalia arjuna, root extract, glibenclamide, alloxan

\section{INTRODUCTION}

Diabetes mellitus, one of the major public health problems worldwide, is a metabolic disorder of multiple etiologies distinguished by a failure of glucose homeostasis with disturbances of carbohydrate, fat and protein metabolism as a result of defects in insulin secretion and/or insulin action. Diabetes mellitus can be managed by diet, physical exercise, and modern drugs (insulin and/or oral hypoglycemic drugs such as sulfonylureas and biguanides). ${ }^{1-3}$

Different extracts from medicinal plants have also been used traditionally to manage diabetes globally, and these are considered as relatively inexpensive, less toxic and with relatively little or no side effects. Terminalia arjuna is a medicinal plant of the genus Terminalia, widely used by Ayurvedic physicians for its curative properties in organic/functional heart problems including angina, hypertension and deposits in arteries. Its bark is astringent and is used in fevers and in fractures and contusions. Bark styptic, tonic, febrifuge and anti-dysenteric; pulverised bark gives relief in symptomatic hypertension and acts as a diuretic in cirrhosis of liver. Fruits tonic and deobstruent. Juice of leaves used in earache. The cardio protective effects of Terminalia are thought to be caused by the antioxidant nature of several of the constituent flavonoids and oligomeric proanthocyanidins, while positive inotropic effects may be caused by the saponin glycosides. In addition to its cardiac effects, Terminalia may 
also be protective against gastric ulcers, such as those caused by NSAIDs. The aim of this study assessed extraction, phytochemical screening and anti-diabetic activity of root extract of Terminalia arjuna. ${ }^{4-9}$

\section{MATERIALS AND METHODS}

\section{Plant material collection}

The plant Terminaliaarjuna(roots) was collected from local area of Bhopal (M.P.) in the month of June, 2018.

\section{Drying}

Drying of fresh plant parts was carried out in sun but under the shade.

\section{Storage}

Dried Terminaliaarjuna(roots) was preserved in plastic bags and closed tightly and powdered as per the requirements.

\section{Extraction Procedure}

Following procedure was adopted for the preparation of acetone extract from the shade dried and powdered herbs:

\section{Defatting of Plant Material}

Terminaliaarjuna(roots) was shade dried at room temperature. The shade dried plant material was coarsely powdered and subjected to extraction with petroleum ether by maceration. The extraction was continued till the defatting of the material had taken place.

\section{Extraction by Maceration process}

Dried powdered of Terminalia arjuna (roots) has been extracted with acetone solvent using sohxlation methodfor $48 \mathrm{hrs}$, filtered and dried using vaccum evaporator at $400 \mathrm{C}$.

Determination of percentage yieldThe percentage yield of each extract was calculated by using following formula:

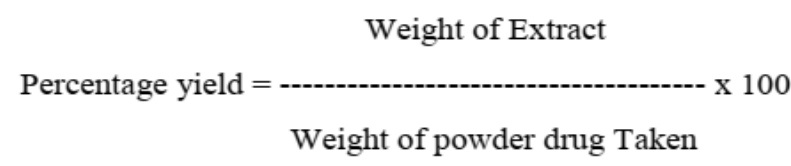

\section{Phytochemical screening ${ }^{10,12}$ :}

Phytochemical examinations were carried out for all the extracts as per the standard methods.

1. Detection of alkaloids: Extracts were dissolved individually in dilute Hydrochloric acid and filtered.

a) Mayer's Test: Filtrates were treated with Mayer's reagent (Potassium Mercuric lodide). Formation of a yellow coloured precipitate indicates the presence of alkaloids.

b) Wagner's Test: Filtrates were treated with Wagner's reagent (lodine in Potassium lodide). Formation of brown/reddish precipitate indicates the presence of alkaloids.

c) Dragendroff's Test: Filtrates were treated with Dragendroff's reagent (solution of Potassium Bismuth lodide). Formation of red precipitate indicates the presence of alkaloids. d) Hager's Test: Filtrates were treated with Hager's reagent (saturated picric acid solution). Presence of alkaloids confirmed by the formation of yellow coloured precipitate.

Detection of carbohydrates: Extracts were dissolved individually in $5 \mathrm{ml}$ distilled water and filtered. The filtrates were used to test for the presence of carbohydrates.

a) Molisch's Test: Filtrates were treated with 2 drops of alcoholic $\alpha$-naphthol solution in a test tube. Formation of the violet ring at the junction indicates the presence of Carbohydrates.

b) Benedict's Test: Filtrates were treated with Benedict's reagent and heated gently. Orange red precipitate indicates the presence of carbohydrates.

c) Fehling's Test: Filtrates were hydrolysed with dil. $\mathrm{HCl}$, neutralized with alkali and heated with Fehling's A \& B solutions. Formation of red precipitate indicates the presence of reducing sugars. 
3. Detection of glycosides: Extracts were hydrolysed with dil. $\mathrm{HCl}$, and then subjected to test for glycosides.

a) Modified Borntrager's Test: Extracts were treated with Ferric Chloride solution and immersed in boiling water for about 5 minutes. The mixture was cooled and extracted with equal volumes of benzene. The benzene layer was separated and treated with ammonia solution. Formation of rose-pink colour in the ammonical layer indicates the presence of anthranol glycosides.

b) Legal's Test: Extracts were treated with sodium nitropruside in pyridine and sodium hydroxide. Formation of pink to blood red colour indicates the presence of cardiac glycosides.

\section{Detection of saponins}

a) Froth Test: Extracts were diluted with distilled water to $20 \mathrm{ml}$ and this was shaken in a graduated cylinder for 15 minutes. Formation of $1 \mathrm{~cm}$ layer of foam indicates the presence of saponins.

b) Foam Test: $0.5 \mathrm{gm}$ of extract was shaken with $2 \mathrm{ml}$ of water. If foam produced persists for ten minutes it indicates the presence of saponins.

\section{Detection of phenols}

a) Ferric Chloride Test: Extracts were treated with 3-4 drops of ferric chloride solution. Formation of bluish black colour indicates the presence of phenols.

\section{Detection of flavonoids}

a) Alkaline Reagent Test: Extracts were treated with few drops of sodium hydroxide solution. Formation of intense yellow colour, which becomes colourless on addition of dilute acid, indicates the presence of flavonoids.

b) Lead acetate Test: Extracts were treated with few drops of lead acetate solution. Formation of yellow colour precipitate indicates the presence of flavonoids.

\section{Detection of proteins and amino acids}

a) Xanthoproteic Test: The extracts were treated with few drops of conc. Nitric acid. Formation of yellow colour indicates the presence of proteins.

b) Ninhydrin Test: To the extract, $0.25 \% \mathrm{w} / \mathrm{v}$ ninhydrin reagent was added and boiled for few minutes. Formation of blue colour indicates the presence of amino acid.

\section{Detection of diterpenes}

a) Copper acetate Test: Extracts were dissolved in water and treated with 3-4 drops of copper acetate solution. Formation of emerald green colour indicates the presence of diterpenes(Roopashreeet al., 2008; Auduet al., 2007; Kokate, 1994).

\section{Qualitative chromatographic analysis}

\section{Thin layer chromatography}

Thin layer chromatography: T.L.C. is based on the adsorption phenomenon. In this type of chromatography mobile phase containing the dissolved solutes passes once the chromatogram was developed the Rf Value of the spot was calculated.

\section{Quantitative estimation of bioactive compounds ${ }^{10,12}$}

\section{Total phenolic content estimation}

Principle: The total phenolic content of the extract was determined by the modified FolinCiocalteu method.

Preparation of Standard: $10 \mathrm{mg}$ Gallic acid was dissolved in $10 \mathrm{ml}$ methanol, various aliquots of $10-50 \mu \mathrm{g} / \mathrm{ml}$ was prepared in methanol

Preparation of Extract: $10 \mathrm{mg}$ of dried extract was dissolved in $10 \mathrm{ml}$ methanol and filter. Two $\mathrm{ml}(1 \mathrm{mg} / \mathrm{ml})$ of this extract was for the estimation of phenol.

Procedure: $2 \mathrm{ml}$ of acetone extract and each standard was mixed with $1 \mathrm{ml}$ of FolinCiocalteu reagent (previously diluted with distilled water $1: 10 \mathrm{v} / \mathrm{v})$ and $1 \mathrm{ml}(7.5 \mathrm{~g} / \mathrm{l})$ of sodium 
carbonate. The mixture was vortexed for $15 \mathrm{~s}$ and allowed to stand for $10 \mathrm{~min}$ for colour development. The absorbance was measured at $765 \mathrm{~nm}$ using a spectrophotometer.

\section{Total flavonoids content estimation}

Principle: Determination of total flavonoids content was based on aluminium chloride method

Preparation of standard: $10 \mathrm{mg}$ quercetin was dissolved in $10 \mathrm{ml}$ acetone, and various aliquots of $5-25 \mu \mathrm{g} / \mathrm{ml}$ were prepared in methanol.

Preparation of extract: $10 \mathrm{mg}$ of dried extract was dissolved in $10 \mathrm{ml}$ acetone and filter. Three $\mathrm{ml}(1 \mathrm{mg} / \mathrm{ml})$ of this extract was for the estimation of flavonoids.

Procedure: $1 \mathrm{ml}$ of $2 \% \mathrm{AlCl} 3$ solution was added to $3 \mathrm{ml}$ of extract or each standard and allowed to stand for $15 \mathrm{~min}$ at room temperature; absorbance was measured at $420 \mathrm{~nm}$.

\section{In -Vivo antidiabetic activity of acetone extract of Terminaliaarjuna(roots)}

Materials and methods ${ }^{9-13}$

\section{Animals:-}

Wistar rats (150-200 g) were group housed $(n=$ 6) under a standard $12 \mathrm{~h}$ light/dark cycle and controlled conditions of temperature and humidity $\left(25 \pm 2{ }^{\circ} \mathrm{C}\right)$. Rats received standard rodent chow and water ad libitum. Rats were acclimatized to laboratory conditions for 7 days before carrying out the experiments. All the experiments were carried in a noise-free room between 08.00 to $15.00 \mathrm{~h}$. Separate group $(n=6)$ of rats was used for each set of experiments. The animal studies were approved by the Institutional Animal Ethics Committee (IAEC), constituted for the purpose of control and supervision of experimental animals by Ministry of Environment and Forests, Government of India, New Delhi, India.

\section{Acute toxicity studies}

Acute oral toxicity was conducted according to themethod of Organisation for Economic Co operation and Development (OECD)(OECD, 2001). Animals were kept fasting providing only water, acetone extract ofroots of Terminaliaarjuna. $(50,100,150,200,300$

$\mathrm{mg} / \mathrm{kg} /$ day) was administered orally for 4 days of six groups of rats $(n=6)$ and the animals were kept under observation for mortality as well as any behavioral changes for evaluation of a possible effect.

\section{Induction of Experimental Diabetes in Rats}

After fasting, diabetes was induced by a single intraperitonealinjection of $120 \mathrm{mg} / \mathrm{kg}$ body weight of 'Alloxan monohydrate'in distilled water. The animals were allowed todrink $5 \%$ glucose solution overnight to overcome thedrug-induced hypoglycaemia. These animals were testedfor diabetes after 15 days and animals with blood glucose(fasting) were selected for experimentation.

\section{Experimental Protocol}

Animals were divided into five groups of 6 rats each.

\section{Table 1: Different Groups of Rats}

\begin{tabular}{|c|c|c|}
\hline 1. & Group I & $\begin{array}{l}\text { Rats served as normal-control and received the vehicle }(0.5 \mathrm{ml} \\
\text { distilled water/day/rat) }\end{array}$ \\
\hline 2. & Group II & $\begin{array}{l}\text { Rats served as diabetic-control and received the vehicle }(0.5 \mathrm{ml} \\
\text { distilled water/day/rat) }\end{array}$ \\
\hline 3. & Group III & $\begin{array}{l}\text { Rats (diabetic) were administered Terminaliaarijuna (100 mg/kg } \\
\text { p.o.) for } 15 \text { days. }\end{array}$ \\
\hline 4. & Group IV & $\begin{array}{l}\text { Rats (diabetic) were administered Terminaliaariunua( } 200 \mathrm{mg} / \mathrm{kg} \\
\text { p.o.) for } 15 \text { days. }\end{array}$ \\
\hline
\end{tabular}

\section{RESULTS}

\section{Determination of Percentage Yield}

Yield of Extraction: the crude extract was obtained after the sohxlation process and then it was kept on water bath for the evaporation 
of solvents completely, so that the percentage yield of extract can be calculated. The yield of extract obtained from sample using Acetonesolvent is depicted in the table 2 .

Table 2: \% Yield of Terminaliaarjuna(roots)

\begin{tabular}{|c|l|c|}
\hline S. No. & Solvent & \% Yield (W/W) \\
\hline 1 & Acetone & $4.3 \%$ \\
\hline
\end{tabular}

\section{Phytochemical screening of extract}

A small portion of the dried extracts were subjected to the phytochemical test using (Kokate, 1994) methods to test for alkaloids, glycosides, saponins, flavonoids, phenolics and diterpenes separately for extract of all samples. Small amount of extract is suitably resuspended into the sterile distilled water to make the concentration of $1 \mathrm{mg}$ per $\mathrm{ml}$.

Table 3: Result of Phytochemical Screening of Acetone extract of Terminalia arjuna(roots)

\begin{tabular}{|c|c|c|}
\hline S.No. & Constituents & Acetone \\
\hline $\mathbf{1 .}$ & Alkaloids & -ve \\
\hline $\mathbf{2 .}$ & Glycosides & -ve \\
\hline $\mathbf{3 .}$ & Flavonoids & +ve \\
\hline $\mathbf{4 .}$ & Diterpenes & -ve \\
\hline $\mathbf{5 .}$ & Phenolics & +ve \\
\hline $\mathbf{6 .}$ & Amino Acids & +ve \\
\hline $\mathbf{7 .}$ & Carbohydrate & +ve \\
\hline $\mathbf{8 .}$ & Proteins & +ve \\
\hline $\mathbf{9 .}$ & Saponins & +ve \\
\hline
\end{tabular}

*Present =+ve, Absent-ve

Table 4: Calculation of Rf. Value

\begin{tabular}{|c|c|c|c|}
\hline $\begin{array}{c}\text { S. } \\
\text { No. }\end{array}$ & Compound & Extract & Rf Value \\
\hline 1. & Gallic acid & $\begin{array}{c}\text { Toluene: Ethyl acetate: Formic acid } \\
(7: 5: 1)\end{array}$ & 0.65 \\
\hline 2. & Quercetin & $\begin{array}{c}\text { Toluene: Ethyl acetate: Formic acid } \\
(5: 4: 1)\end{array}$ & 0.82 \\
\hline
\end{tabular}

Total phenolic content estimation (TPC)

The total phenolic content (TPC) was expressed as $\mathrm{mg} / 100 \mathrm{mg}$ of Gallic acid equivalent of dry extract sample using the equation obtained from the calibration curve: $Y=0.011 X+0.011, R 2=0.998$, where $X$ is the Gallic acid equivalent (GAE) and $Y$ is the absorbance.

\section{Calibration curve of Gallic acid}

Table 5: Preparation of calibration curve of Gallic acid

\begin{tabular}{|c|c|c|}
\hline S. No. & Concentration & Absorbance \\
\hline $\mathbf{0}$ & 0 & 0 \\
\hline $\mathbf{1}$ & 10 & 0.135 \\
\hline $\mathbf{2}$ & 20 & 0.247 \\
\hline $\mathbf{3}$ & 30 & 0.364 \\
\hline $\mathbf{4}$ & 40 & 0.474 \\
\hline $\mathbf{5}$ & 50 & 0.581 \\
\hline
\end{tabular}

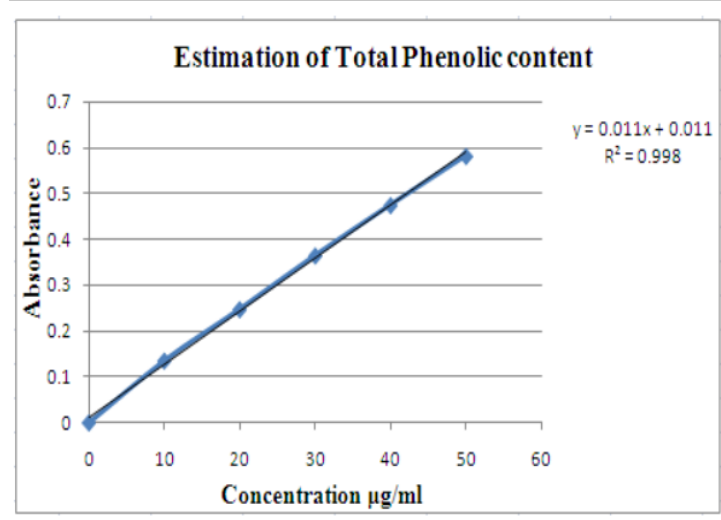

Figure 1: Graph of estimation of total phenolic content Total flavonoids content estimation (TFC)

Total flavonoids content was calculated as Quercetin equivalent $(\mathrm{mg} / \mathrm{g})$ using the equation based on the calibration curve: $\mathrm{Y}=0.040 \mathrm{X}+\mathbf{0 . 0 0 9}, \mathbf{R} \mathbf{2}=\mathbf{0 . 9 9 9}$, where $\mathrm{X}$ is the Quercetin equivalent (QE) and $Y$ is the absorbance.

Table 6: Preparation of calibration curve of Quercetin

\begin{tabular}{|c|c|c|}
\hline S. No. & Concentration $(\mu \mathrm{g} / \mathrm{ml})$ & Absorbance \\
\hline $\mathbf{0}$ & 0 & 0 \\
\hline $\mathbf{1}$ & $\mathbf{5}$ & 0.216 \\
\hline $\mathbf{2}$ & 10 & 0.425 \\
\hline $\mathbf{3}$ & 15 & 0.625 \\
\hline $\mathbf{4}$ & 20 & 0.815 \\
\hline $\mathbf{5}$ & 25 & 1.021 \\
\hline
\end{tabular}




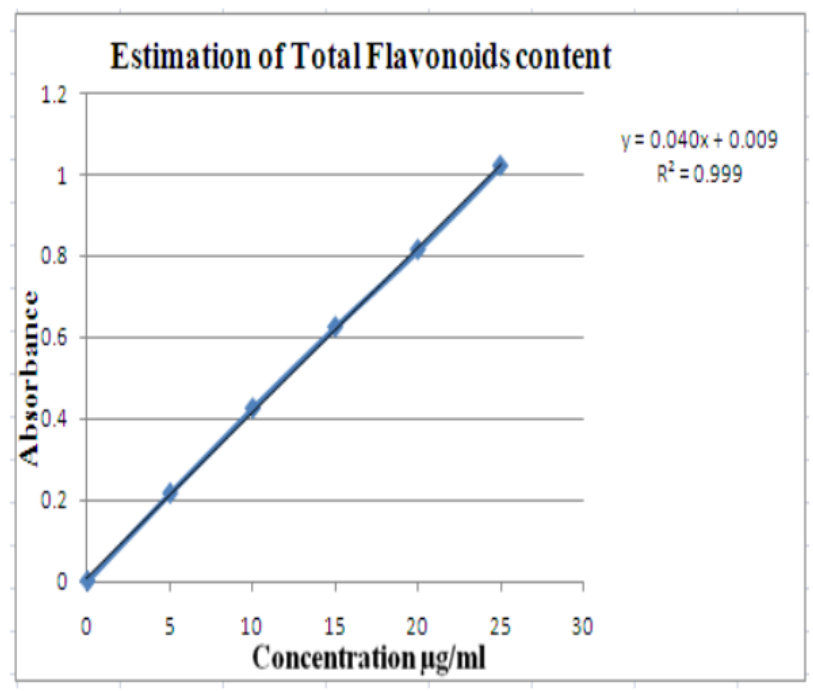

Figure 2: Graph of estimation of total flavonoids content

Table 7: Estimation of total phenolics and total flavonoids content of Terminalia arjuna(roots)

\begin{tabular}{|c|c|c|c|}
\hline S. No & Extracts & $\begin{array}{c}\text { Total phenolic content } \\
\text { (mg/100mg of dried } \\
\text { extract) }\end{array}$ & $\begin{array}{c}\text { Total flavonoids content } \\
\text { (mg/100mg of dried } \\
\text { extract) }\end{array}$ \\
\hline 1. & Acetone & 3.645 & 0.790 \\
\hline
\end{tabular}

The total phenolic and flavonoids content of the Acetone extract were also determined.

Table 8: Effect of Terminalia arjuna root extract treatment on blood glucose $(\mathrm{mg} / \mathrm{dl})$ in normal and diabetic rats

\begin{tabular}{|c|c|c|c|c|}
\hline \multirow[t]{2}{*}{ Group } & \multirow[t]{2}{*}{ Treatment } & \multicolumn{3}{|c|}{ Blood glucose (mg/dl) } \\
\hline & & Days 0 & Days 8 & Days 15 \\
\hline I & Normal & $85.00 \pm 3.12$ & $102.00 \pm 2.15$ & $108.00 \pm 3.69$ \\
\hline II & Diabetic Control & $271.51 \pm 8.35$ & $280.00 \pm 11.12^{5}$ & $286.00 \pm 14.36^{7}$ \\
\hline III & $\begin{array}{c}\text { Diabetic + Terminaliaarjuma } \\
(100 \mathrm{mg} / \mathrm{kg})\end{array}$ & $251.00 \pm 2.50$ & $195.00 \pm 3.16^{\text {mit }}$ & $176.00 \pm 2.36^{\operatorname{tw}}$ \\
\hline IV & $\begin{array}{c}\text { Diabetic + Terminaliaarjuma } \\
(200 \mathrm{mg} / \mathrm{kg})\end{array}$ & $236.00 \pm 3.00$ & $165.00 \pm 4.17^{\mathrm{mit}}$ & $134.00 \pm 5.52^{m+1}$ \\
\hline $\mathrm{V}$ & $\begin{array}{c}\text { Diabetic + Glibenclamide } \\
(600 \mathrm{mg} / \mathrm{kg})\end{array}$ & $195.00 \pm 4.00$ & $118.00 \pm 3.1$ & $110 \pm 3.25$ \\
\hline
\end{tabular}

Values are expressed as mean \pm S.E.M $(n=6)$. Values are statistically significant at \#p<0.001 vs.normal group; $* P<$ $0.001, * * P<0.01 v$ s. diabetic control group (Two-way ANOVA test)

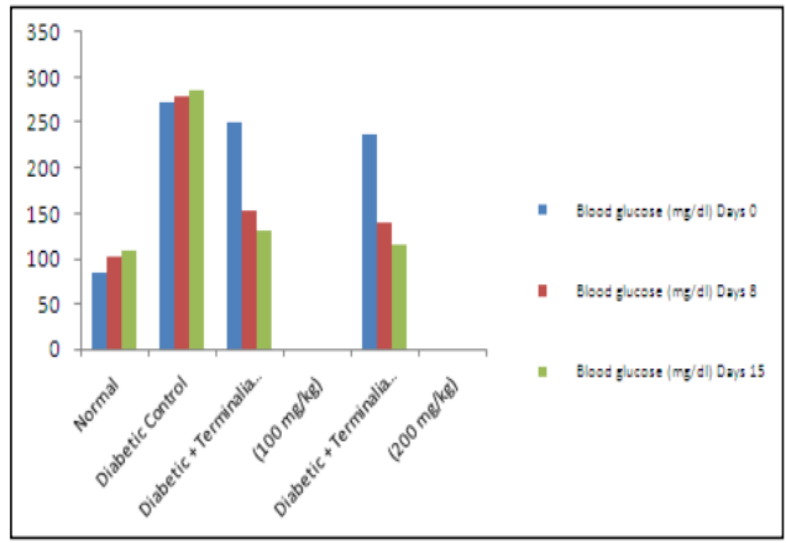

Figure 3: Effect of Terminalia arjuna root extract treatment on blood glucose $(\mathrm{mg} / \mathrm{dl})$ in normal and diabetic rats

Table 8: Effect of Terminalia arjuna treatment on biochemical parameters in normal and diabetic rats

\begin{tabular}{|c|c|c|c|c|c|}
\hline Group & Treatment & $\begin{array}{c}\mathrm{TC} \\
(\mathrm{mg} / \mathrm{dL})\end{array}$ & $\begin{array}{c}\mathrm{TG} \\
(\mathrm{mg} / \mathrm{dL})\end{array}$ & $\begin{array}{c}\text { Total } \\
\operatorname{protein}(\mathrm{g} / \mathrm{dl})\end{array}$ & $\begin{array}{l}\text { Urine } \\
\text { Sugar }\end{array}$ \\
\hline I & Normal & $87.00 \pm 3.00$ & $78.00 \pm 2.50$ & $7.30 \pm 0.30$ & - \\
\hline II & Diabetic Control & $182.0 \pm 3.00$ & $119.0 \pm 3.50$ & $3.50 \pm 0.25$ & ++ \\
\hline III & $\begin{array}{c}\text { Diabetic }+ \text { Terminaliaarjuna } \\
(100 \mathrm{mg} / \mathrm{kg})\end{array}$ & $108.9 \pm 7.55^{*}$ & $85.89 \pm 3.50^{*}$ & $5.30 \pm 0.30^{*}$ & + \\
\hline IV & $\begin{array}{c}\text { Diabetic }+ \text { Terminaliaarjuna } \\
(200 \mathrm{mg} / \mathrm{kg})\end{array}$ & $102.6 \pm 2.50^{+t . t}$ & $82.30 \pm 5.50^{*}$ & $7.00 \pm 0.35^{*}$ & + \\
\hline V & $\begin{array}{l}\text { Diabetic }+ \text { Glibenclamide } \\
\qquad(600 \mathrm{mg} / \mathrm{kg})\end{array}$ & $90.5 \pm 3.00$ & $80.21 \pm 0.23$ & $7.20 \pm 0.21$ & + \\
\hline
\end{tabular}

Values are expressed as mean \pm S.E.M $(n=6)$.Values are statistically significant at $\# p<0.001$ vs. normal group; $* P<0.001, * * P<0.01 v$ s. diabetic control group (One-way ANOVA followed by Tukey's post hoc test).

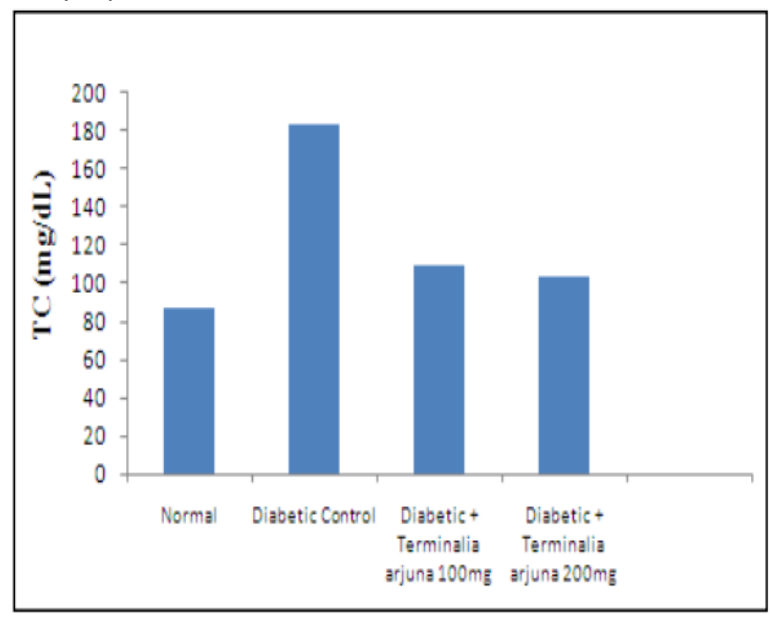

Figure 4: Effect of Terminalia arjuna treatment on biochemical parameters in normal and diabetic rats 


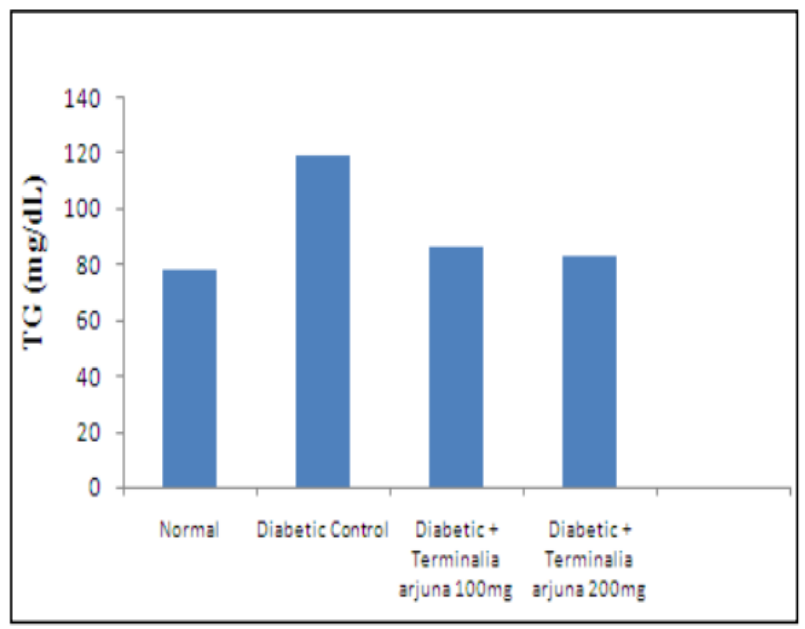

Figure 5: Effect of Terminalia arjuna treatment on triglyceride in normal and diabetic rats

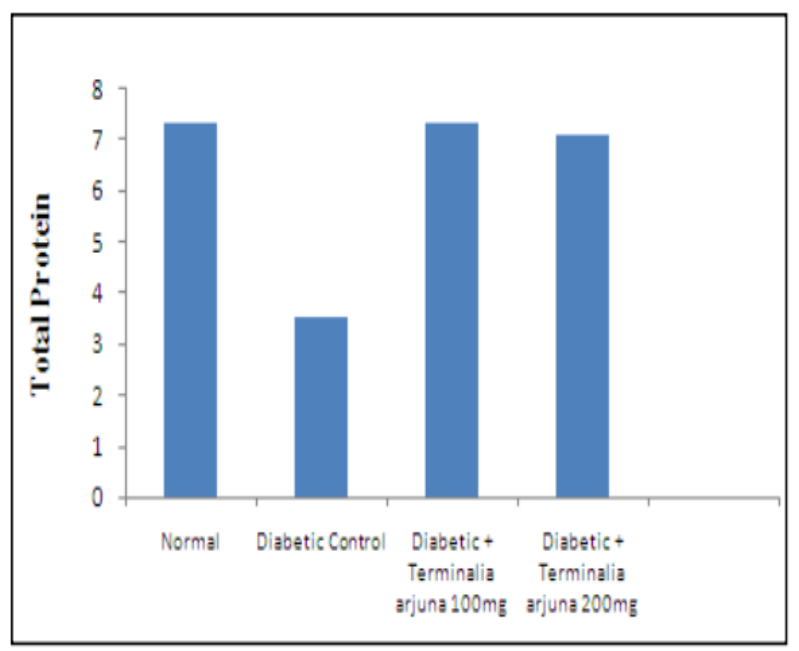

Figure 6: Effect of Terminalia arjuna treatmentin normal and diabetic rats (Total protein)

Table 9: Effects of Terminalia arjuna extracts on body weight

\begin{tabular}{|c|c|c|c|}
\hline Group & Treatment & $\begin{array}{c}\text { Initial weight } \\
\text { (g) }\end{array}$ & $\begin{array}{c}\text { Final weight } \\
(\mathrm{g})\end{array}$ \\
\hline I & Normal & $155.00 \pm 8.90$ & $199.10 \pm 9.06$ \\
\hline II & Diabetic Control & $175.00 \pm 8.40$ & $155.00 \pm 8.78$ \\
\hline III & $\begin{array}{c}\text { Diabetic + } \\
\text { Terminaliaarjuna } \\
(100 \mathrm{mg} / \mathrm{kg})\end{array}$ & $160.00 \pm 10.00$ & $175.00 \pm 7.32$ \\
\hline IV & $\begin{array}{c}\text { Diabetic }+ \\
\text { Terminaliaarjuna } \\
(200 \mathrm{mg} / \mathrm{kg})\end{array}$ & $170.00 \pm 9.20$ & $189.00 \pm 8.42$ \\
\hline V & $\begin{array}{c}\text { Diabetic + Glibenclamide } \\
(600 \mu \mathrm{\mu} / \mathrm{kg})\end{array}$ & $175.00 \pm 7.80$ & $190.85 \pm 8.16$ \\
\hline
\end{tabular}

Values are expressed as mean \pm SD of six samples from each group. (Two-way ANOVA test).

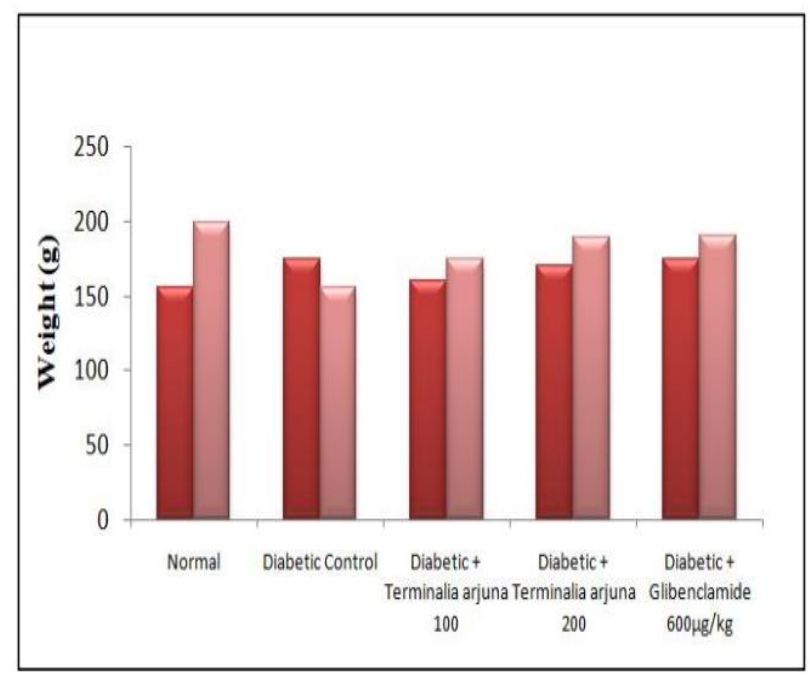

Figure 7: Effects of Terminalia arjuna extracts on body weight

\section{DISCUSSION}

Medicinal plants are used by the population of developing countries as alternative therapy. During recent years herbal medicine has become an increasingly scientifically based system of healing. Due to demands from both the public and medical establishments, studies leading to the scientific explanation of plant therapeutic capabilities are allowing this practice to gain increasing credibility and acceptance within the medical community. Man from his first awaking, has sought to combat the control disease and pain, with assistance, inspiration and guidance from its natural environment as far as life is concerned subject of priority is health.

But despite effort to maintain good health, man animals a like still confront disease conditions which are due to exposure to physiopathological agents. Diabetes mellitus is a combination of heterogeneous disorders commonly presenting with episodes of hyperglycaemia and glucose intolerance, as a result of lack of insulin, defective insulin action, or both. Such complications arise due to derangements in the regulatory systems for 
storage and mobilization of metabolic fuels, including the catabolism and anabolism of carbohydrates, lipids and proteins emanating from defective insulin secretion, insulin action, or both. Terminalia arjuna (Combretaceae), commonly known as Arjun and Arjuna was first described by Ayurvedic sage Vagbhatta as a tonic and is in use in India for past 1500 years. Terminalia arjuna widely used by Ayurvedic physicians for its curative properties in organic/functional heart problems including angina, hypertension and deposits in arteries. Its bark is astringent and is used in fevers and in fractures and contusions. Bark styptic, tonic, febrifuge and anti-dysenteric; pulverised bark gives relief in symptomatic hypertension and acts as a diuretic in cirrhosis of liver. The extractive value of extract of Terminalia arjuna was investigated and represented in Table No. 7.1. From the present study it was found that, the extractive value of Terminalia arjuna (roots) in acetone extract was $4.3 \%$.

Terminalia arjuna have beneficial therapeutic effects in traditional Indian system of medicine. Various phytochemicals that are present in it are responsible for these therapeutic effects. The quantitative phytochemical analysis of Terminalia arjuna was carried out. (Table No. 7.2) It revealed the presence of saponins, flavonoids, phenol, carbohydrates, proteins and amino acids in acetone extract.

TLC analysis of the acetone extract of the roots was carried out using the solvent system Toluene: Ethyl acetate: Formic acid (7:5:1) and Toluene: Ethyl acetate: Formic acid (5:4:1) for gallic acid and quercetin respectively. The $\mathrm{Rf}$ value (0.65) and six $\mathrm{Rf}$ value (0.82) were found in TLC plate of gallic acid and quercetin extract respectively.

The total phenolic and flavonoids content of the Acetone extract were also determined. Total phenolics and Total flavanoid content of roots extract also highest $(3.645 \mathrm{mg}$ gallic acid/100mg and $0.790 \mathrm{mg}$ quarcetin $/ 100 \mathrm{mg}$ ).
In vivo studies were performed to ascertain antidiabetic potential of acetone crude extracts. Diabetes Mellitus is the highly prevalent metabolic disorder with alarming morbidity associated with modern lifestyle in the present world. Diabetes Mellitus, if remain untreated progresses with many serious complications and finally ends at the cost of life of patient. Diabetes mortality increased from approximately 68,000 deaths in 1999 to 74,000 deaths in 2003.

Diabetes is the sixth leading recorded cause of death in the USA. The acute oral toxicity studies and selection of doses was carried out as per guidelines of Organization for Economic Co-operation and Development (OECD), draft guidelines 423 received from Committee for the Purpose of Control and Supervision of Experiments on Animals (CPCSEA), Ministry of Social Justice and Empowerment, Government of India.

It is evident from the present investigation that alloxan administration at the dose of 120 $\mathrm{mg} / \mathrm{kg}$ body weight causes significant diabetogenic response in rats. Blood glucose levels were measured randomly on 0-6 hrs of study. The increase in glucose levels in diabetic control group was found to be significant $(\mathrm{P}<$ $0.05)$ when compared to normal control group.

The mechanism of action of the standard drug glibenclamide binding with its receptor leads to the closure of the potassium channels which opens calcium channels for influx of $\mathrm{Ca} 2+$ ions into the cytoplasm and release of insulin from the pancreatic islets. These $\mathrm{K}+$ channels are responsive to ATP/ADP ratio and close when the ratio increases because of an increase in glucose metabolism. With chronic glibenclamide treatment, insulin production is not increased and may return to pretreatment values, but insulin efficacy continues and is thought to involve extra pancreatic mechanisms to increase insulin sensitivity in target tissues, such as liver and muscle as well as in other cells like monocytes and 
erythrocytes. This also leads to decrease hepatic glycogenolysis, gluconeogenesis and blood-glucose concentrations.

\section{CONCLUSION}

Diabetes Mellitus is a metabolic disorder affecting fat, carbohydrate and protein metabolisms, complicated with multi-organs regression in the later period. Diabeticdyslipidemic rats induced by alloxan and high-fat and high-cholesterol diets are easily obtained and steady animal models for simulating clinically diabetic individuals complicated with dyslipidemia and also for screening drugs with hypoglycemic and/or hypolipidemic effects. Diabetes is the wide therapeutic area with unmet needs though research work is being done in this direction to treat each and every minor consequences related with disease.

The increased in blood sugar is accompanied with the increase in TC, TG and Total protein. It is well known that in uncontrolled type 2 diabetes mellitus, there will be an increase in TC, TG and protein; it is encouraging that the 15-day treatment of extracts associated with reduced the elevated levels of TC, TG as compared to negative control in diabetic animals. Changes in initial and final body weight of normal control and experimental groups are shown in Table. Marked body weight loss was observed in diabetic rats. The data obtained from this study showed that the treatment of extracts and glibenclamide protects the diabetic rats from massive body weight loss, when given orally, daily for 15 days. Extracts and glibenclamide-treated rats showed a recovery in final body weight which was close to that of normal control rats. In order to establish the scientific basis for the utility of Terminalia arjuna in the treatment of diabetes, evaluation of the hypoglycemic activity of the methanolic extract and solvent fractions on normal and diabetic rats was carried out.
We conclude that the root extract of Terminalia arjuna have potent antidiabetic effects in alloxan-induced diabetic rats. The present investigation has also opened avenues for further research especially with reference to the development of potent formulation for diabetes mellitus from root of Terminalia arjuna.

\section{REFERENCES}

1. Powers AC. Diabetes Mellitus. In: Longo DL, Kasper DL, Jameson JL, Fauci AS, Hauser SL, Loscalzo J, editors. Harrison's principles of Internal Medicine. 18th ed. New Delhi: McGraw-Hill Medical publishing division; 2012. p. 2968-3002

2. Davis SN. Insulin, oral hypoglycemic agents, and the pharmacology of the endocrine pancreas. In: Brunton LL, Lazo JS, Parker KL, editors. Goodman and Gilman's the pharmacological basis of therapeutics. 11th ed. New York: McGraw-Hill, Medical Publishing Division; 2006. p. 1613-45.

3. Imran, M., Khan, M., Akhtar, R., Ahmed, S., \& Rageeb, M. (2016). Antidiabetic and hypolipidemic effect of methanol extract of Stereospermum colais fruit in streptozotocin induced diabetic rats. Journal of Drug Delivery and Therapeutics, 6(4), 41-47.

4. Umashanker M, Shruti S. Traditional Indian herbal medicine used as antipyretic, antiulcer, anti-diabetic and anticancer: Areview. Int J Res in Pharm and Chem 2011; 1:1152-9.

5. Tiwari, A.K., Gode, J.D. and Dubey, G.P. Effect of T.arjuna bark powder on serum lipids and lipoproteins in hypercholesterolemic rabbits. Indian Drugs.1989, 26:664.

6. Tiwari, A.K., Gode, J.D. and Dubey, G.P. Effect of T.arjuna on lipid profiles of rabbits fed hypercholesterolemic diet. Int. J. Crude Drugs Res. 1990, 28:43-47

7. Pathak, S.R., Upadhyay, L., Singh, R.H., Dubey, G.P and Udupa, K.N. Effect of 
T.arjuna on autocodial and lipid profiles of rabbits. Indian drugs. 1990, 27,221-227.

8. Shaila, H.P., Udupa, S.L., Udupa., A.L and Nair, N.S. Effect of T. arjuna on experimental hyperlipidemia in rabbits. J. Pharmacogn. 1997, 35:1-4.

9. Ram, A., Lauria, P., Gupta, R.P., Kumar, P. and Pandsharma, V.N. Hypocholesterolemic effects of T.arjuna tree bark. J. Ethanopharmacol. 1997, 55-165-169

10. Ghosh R, Sharatchandra K, Rita S, Thokchom IS. Hypoglycemic activity of Ficus hispida (bark) in normal and diabetic albino rats. Indian J Pharmacol 2004; 36:222-5.
11. Ghosh MN. Toxicity Studies. Fundamentals of Experimental Pharmacology. 4th ed. Kolkata: Hilton and Company; 2005. p. 176-89.

12. Hakkim FL, Girija S, Kumar RS, Jalaluddeen MD. Effect of aqueous and ethanol extracts of Cassia auriculata L. flowers on diabetes using alloxan induced diabetic rats. Int J Diabetes and Metabolism 2007; 15:100-6.

13. Regi Raphael, K., Sabu, M.C and Ramadasan Kuttan. Hypoglycemic effect of menthanol extract of Phyllanthus amarus schum and Thonn on alloxan induced diabetes mellitus in rats and its relation with antioxidant potential, Indian, J. Exp. Biol.2002; 40:905-909. 